\title{
Aplikasi Algoritma Tabu Search dan Safety Stock Pada Penentuan Rute Distribusi Air Mineral di Daerah Istimewa Yogyakarta
}

\author{
Anita Nurul Firdaus dan Pipit Pratiwi Rahayu \\ Program Studi Matematika Fakultas Sains dan Teknologi, UIN Sunan Kalijaga, Jl. Marsda Adisucipto \\ No. 1 Yogyakarta, Indonesia
}

Korespondensi; Pipit Pratiwi Rahayu, Email: pipitprahayu@yahoo.com

\begin{abstract}
Abstrak
Pendistribusian produk berperan penting dalam dunia industri. Salah satu usaha yang dapat dilakukan perusahaan untuk mengoptimalkan pendistribusian produk adalah meminimalkan biaya tranportasi melalui penentuan rute optimal kendaraan yang disebut dengan VRP (Vehicle Routing Problem). Tujuan dari VRP adalah menentukan rute optimal yaitu rute dengan jarak minimum untuk mendistribusikan produk kepada konsumen. Salah satu variasi VRP adalah Capacitated Vehicle Routing Problem (CVRP), yaitu VRP dengan kendala kapasitas kendaraan. Kasus CVRP tersebut dapat diselesaikan dengan menggunakan Algoritma Tabu Search. Cara kerja Algoritma Tabu Search dimulai dengan penentuan initial solution menggunakan Nearest Neighbor, evaluasi move menggunakan Exchange, 2-Opt, Relocated, dan Cross Exchange, update Tabu List, kemudian apabila kriteria pemberhentian terpenuhi maka proses Algoritma Tabu Search berhenti jika tidak, maka kembali pada evaluasi move. Proses perhitungan Algoritma Tabu Search dilakukan secara manual pada PT IAP. Setiap perusahaan distributor atau pun jasa selalu mengadakan persediaan, salah satunya adalah Safety Stock. Perhitungan sederhana Safety Stock dapat membantu menyelesaikan persediaan pengaman yang harus dipersiapkan perusahaan untuk mengurangi tingkat kerugian. Berdasarkan proses perhitungan manual diperoleh solusi pendekatan optimal yaitu rute dengan total jarak terpendek sebesar 138,834 km dan nilai untuk Safety Stock adalah \pm 9 karton.
\end{abstract}

Kata Kunci: Algoritma Tabu Search; Capacitated Vehicle Routing Problem (CVRP); Nearest Neighbor, Safety Stock

\begin{abstract}
Distribution of the product play an important role in the industry field. The effort done by the companies to optimize the distribution is minimize transportation fee by deciding the shortest route of the vehicle, known as Vehicle Routing Problem (VRP). The purpose of VRP is to determine the optimal route of the route with a minimum distance to distribute product to the consumer. One of the varieties of VRP is Capacitated Vehicle Routing Problem (CVRP), which is VRP with vehicle capacity problems. CVRP case can be solved by using Tabu Search Algorithm. How it works Tabu Search Algorithm starts with the determination of the initial solution using the Nearest Neighbor, evaluating the move using Exchange, 2-Opt, Relocated, and Cross Exchange, updates Tabu List, then when the criteria for termination are met then the Tabu Search algorithm stop if not, then go back to the evaluation of the move. Tabu Search Algorithm calculation process is done manually PT IAP. Every distributor or service company always hold inventory, one of them is Safety Stock. The simple calculation of Safety Stock can help solve the safety availability that should be prepared by the companies and reduce the level of losses. Based on the manual calculation process obtained optimal solution approach that is route with the shortest route to the optimal total distance of $138,834 \mathrm{~km}$ and the value of safety stock is \pm 9 cartons.
\end{abstract}

Keywords: Capacitated Vehicle Routing Problem (CVRP); Nearest Neighbor, Safety Stock; Tabu Search Algorithm

\section{Pendahuluan}

Pada dunia industri, logistik memiliki peranan penting dalam meningkatkan kinerja suatu perusahaan. Kemampuan perusahaan untuk mengelola logistik secara efektif dan efisien dapat mempengaruhi biaya dan tingkat pelayanan terhadap konsumen sehingga dapat bersaing dengan perusahaan sejenis lainnya. 
Salah satu usaha yang dapat dilakukan perusahaan untuk mengoptimalkan pendistribusian produk adalah meminimalkan biaya tranportasi melalui penentuan rute optimal kendaraan yang disebut Vehicle Routing Problem (VRP). Kasus VRP merupakan bagian TSP dengan menyertakan kendala satu kendaraan dengan kapasitas sehingga digolongkan ke dalam NP-Hard Problem. Secara teori ataupun praktik pada dunia nyata memiliki permasalahan yang sangat banyak dan kompleks sehingga sulit untuk dipecahkan. Kasus NP-Hard dapat diselesaikan menggunakan pendekatan solusi optimal dengan metode heuristik. Dibandingkan dengan metode heuristik klasik, metaheuristik menunjukkan pencarian solusi yang lebih teliti. Salah satu metode metaheuristik yang dapat diaplikasikan untuk menuntun prosedur pencarian local heuristik untuk menjelajahi daerah solusi di luar titik optimal lokal [9].

Algoritma Tabu Search dapat digunakan untuk mencari solusi optimal VRP yaitu rute yang memiliki total jarak tempuh minimum dengan mempertimbangkan kapasitas kendaraan. Langkah Algoritma Tabu Search dimulai dengan penentuan initial solution menggunakan Nearest Neighbor, evaluasi move menggunakan metode Exchange, 2-Opt, Relocated, dan Cross Exchange, update Tabu List, kemudian apabila kriteria pemberhentian terpenuhi maka proses Algoritma Tabu Search berhenti jika tidak, maka kembali pada evaluasi move. Perhitungan sederhana Safety Stock bertujuan untuk menyeimbangkan jumlah persediaan dengan jumlah permintaan konsumen. Keseimbangan tersebut tentunya akan mendatangkan keuntungan bagi perusahaan karena kemungkinan akan adanya modal macet yang berbentuk persediaan akan semakin kecil sehingga proses perputaran modal dari perusahaan akan lebih lancar. Algoritma Tabu Search dapat memudahkan pencarian solusi optimal VRP yang lebih efektif dan efisien pada PT IAP Yogyakarta.

\section{Landasan Teori}

\section{Teori Graf}

Graf adalah kumpulan simpul (nodes) yang dihubungkan satu sama lain melalui sisi (edge). Suatu graf $G$ merupakan pasangan himpunan $(V, E)$ ditulis dengan notasi $G=(V, E)$, dimana $V$ adalah himpunan berhingga dan tak kosong dari simpul (node) sedangkan $E$ adalah himpunan sisi (edge) yang menghubungkan sepasang elemen tidak berurutan dari $V$. Elemen dari $V$ dinamakan simpul (node), $V=\left\{v_{1}, v_{2}, v_{3}, \ldots, v_{n}\right\}$ dan elemen dari $E$ dinamakan sisi (edge), $E=\left\{e_{1}, e_{2}, e_{3}, \ldots, e_{n}\right\}[10]$.

\section{Graf Berarah Berbobot}

Graf berarah berbobot (weighted directed graph) adalah graf yang setiap node diberikan orientasi arah dan memiliki bobot [22]. Graf berarah berbobot sering digunakan untuk menggambarkan aliran proses, peta lintas Kota dan lain-lain. Lebih lanjut, pada graf berarah berbobot tidak memperbolehkan adanya sisi ganda atau multiple edges.

\section{Graf Hamilton}

Sebuah lintasan pada graf $G$ yang melalui tiap node di dalam graf tersebut tepat satu kali disebut lintasan Hamilton, sedangkan sebuah sirkuit pada graf $G$ yang melalui tiap node tepat satu kali disebut sebagai sirkuit Hamilton [22].

\section{Travelling Salesman Problem (TSP)}

Travelling salesman problem (TSP) merupakan suatu permasalahan untuk menemukan rute perjalanan terpendek dari kota asal atau depot kemudian mengunjungi seluruh kota konsumen yang harus dilalui satu kali dan kembali lagi ke depot. TSP dapat direpresentasikan pada sebuah graf $G=(V, E)$, dimana $V$ adalah simpul (node) yang merepresentasikan kota, dan $E$ adalah sisi yang merepresentasikan jalan yang menghubungkan kota tersebut. Secara umum model matematika untuk TSP adalah sebagai berikut [28]:

Diberikan $v_{i j}$ adalah jarak dari Kota $i$ ke Kota $j\left(v_{i j}\right.$ nonnegative) dan $n$ adalah jumlah Kota yang akan dilewati. Fungsi tujuan untuk meminimumkan total jarak tempuh perjalanan salesman. Jika $Z$ adalah fungsi tujuan maka;

$$
\operatorname{Min} Z=\sum_{i=1}^{n} \sum_{j=1}^{n} v_{i j} x_{i j}
$$


Didefinisikan variabel keputusan:

$$
x_{i j}= \begin{cases}1, & \text { Jika salesman melakukan perjalanan dari kota } i \text { ke kota } j \\ 0, & \text { selainnya }\end{cases}
$$

1. Setiap kota dikunjungi 1 kali

$$
\begin{gathered}
\sum_{i=1}^{n} x_{i j}=1, \text { untuk } j=1,2, \ldots, n \\
\sum_{j=1}^{n} x_{j i}=1, \text { untuk } i=1,2, \ldots, n \\
x_{i j}=0, \text { untuk } i=j
\end{gathered}
$$

2. Variabel keputusan $x_{i j}^{k}$ merupakan bilangan biner

$$
x_{i j} \in\{0,1\}, \forall i, j=1,2, \ldots, n
$$

\section{Capacitated Vehicle Routing Problem (CVRP)}

Vehicle Routing Problem (VRP) merupakan bagian dari TSP, artinya VRP merupakan TSP dengan menyertakan kendala satu kendaraan dengan kapasitas [25]. Beberapa komponen beserta karakteristiknya yang terdapat dalam masalah VRP yaitu; depot, jaringan jalan, konsumen, kendaraan, pengemudi [32].

Capacitated Vehicle Routing Problem (CVRP) merupakan salah satu variasi dari masalah VRP dengan penambahan kendala kapasitas kendaraan yang terbatas. CVRP dapat direpresentasikan sebagai suatu graf berarah berbobot (weighted directed graph) dilambangkan dengan $D=(V, A)$ dimana $V=$ $\left\{v_{i} \mid i=1,2, \ldots, n\right\}$ dapat pula ditulis dengan $V=\left\{v_{1}, v_{2}, v_{3}, \ldots, v_{n}\right\}$ adalah himpunan nodes dan $A=$ $\left\{\left(v_{i}, v_{j}\right) \mid v_{i}, v_{j} \in V_{i \neq j}\right\}$ adalah himpunan sisi (edges) yang menghubungkan himpunan nodes. Node $v_{i}$ dinyatakan sebagai depot dan yang lainnya adalah konsumen. Setiap elemen dari edges menyatakan jarak. Setiap nodes memiliki permintaan (demand) yang dinotasikan sebagai $q_{i}$ dengan $i=$ $\{1,2,3, \ldots, n\}$. Himpunan $K=\left\{k_{1}, k_{2}, k_{3}, \ldots, k_{m}\right\}$ merupakan kumpulan kendaraan yang homogen. Kapasitas kendaraan yang digunakan dinotasikan dengan $Q$ [31].

Diberikan $v_{i j}$ adalah jarak dari node $i$ ke node $j\left(v_{i j}\right.$ merupakan bilangan nonnegative). Jarak diasumsikan simetrik $\left(v_{i j}=v_{j i}\right)$ dan $\left(v_{i i}=v_{j j}=0\right)$. Permasalahan tersebut kemudian dapat dibuat menjadi model matematika dengan tujuan meminimumkan total jarak tempuh perjalanan kendaraan. Didefinisikan variabel keputusan:

$$
\begin{aligned}
x_{i j}^{k} & = \begin{cases}1, & \text { Jika kendaraan } k \text { mengunjungi node } v_{j} \text { setelah node } v_{i} \\
0, & \text { selainnya }\end{cases} \\
y_{i}^{k} & = \begin{cases}1, & \text { Jika node } v_{i} \text { dilayani oleh kendaraan } k \\
0, & \text { selainnya }\end{cases}
\end{aligned}
$$

Keterangan variabel:

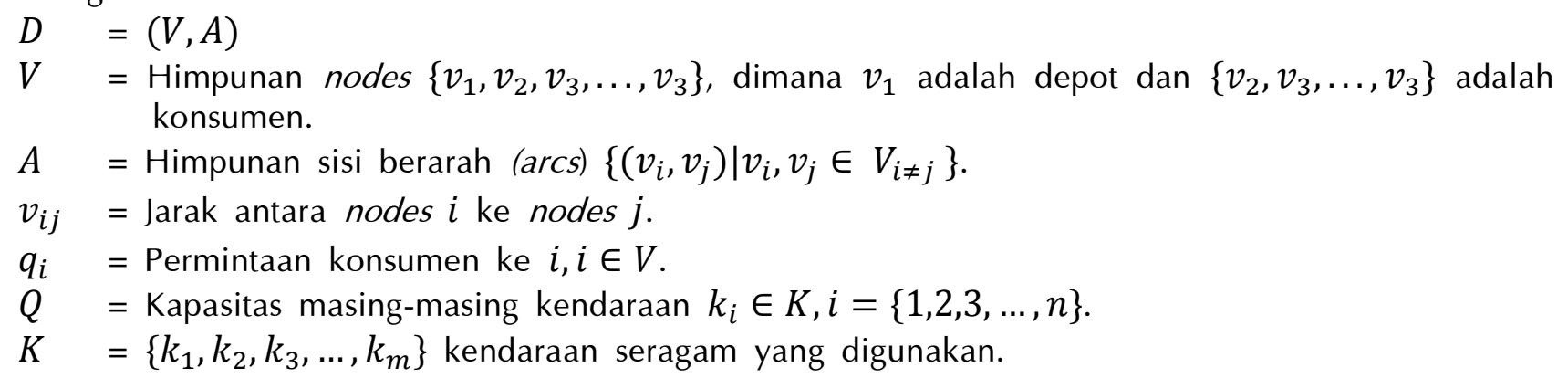


Fungsi tujuan untuk meminimumkan total jarak tempuh kendaraan. Jika $Z$ adalah fungsi tujuan, maka:

$$
\operatorname{Min} Z=\sum_{i=1}^{n} \sum_{j=1}^{n} \sum_{k=1}^{m} v_{i j} x_{i j}^{k}
$$

Kendala:

1. Setiap node hanya boleh dikunjungi tepat satu kali oleh 1 kendaraan.

$$
\sum_{k=1}^{m} \sum_{j=1}^{n} x_{i j}^{k}=1, \forall i \in V
$$

2. Kendaraan yang telah mengunjungi node $i$, kendaraan $k$ harus meninggalkan node tersebut menuju node lain.

$$
\sum_{j=1}^{n} x_{i j}^{k}-\sum_{j=1}^{n} x_{j i}^{k}=0, \forall i \in V, \forall k \in K
$$

3. Total jumlah permintaan konsumen dalam satu rute tidak melebihi kapasitas kendaraan.

$$
\sum_{i=1}^{n} q_{i} \sum_{j=1}^{n} x_{i j}^{k} \leq Q, \forall k \in K
$$

4. Setiap rute perjalanan kendaraan berakhir dan didepot.

$$
\sum_{j=1}^{n} x_{1 j}^{k}=1, \forall k \in K
$$

5. Setiap rute perjalanan kendaraan berakhir dan didepot.

$$
\sum_{j=1}^{n} x_{i 1}^{k}=1, \forall k \in K
$$

6. Variabel keputusan $x_{i j}^{k}$ merupakan bilangan biner.

$$
x_{i j}^{k}\{0,1\}, \forall i, j \in V, \forall k \in K
$$

Variabel keputusan hanya akan terdefinisi jika jumlah permintaan node $v_{i}$ dan node $v_{j}$ tidak melebihi kapasitas kendaraan. Apabila kapasitas kendaraan tidak memadahi untuk konsumen berikutnya maka kendaraan harus mengisi muatan di depot sehingga akan terbentuk rute baru.

\section{Algoritma Tabu Search}

Konsep dasar dari Algoritma Tabu Search yaitu menuntun setiap tahapannya agar dapat menghasilkan solusi yang paling optimum tanpa terjebak ke dalam solusi awal yang ditemukan selama tahapan ini berlangsung. Tujuan dari Algoritma Tabu Search yaitu mencegah terjadinya perulangan dan ditemukannya solusi yang sama pada suatu iterasi yang akan digunakan lagi pada iterasi selanjutnya. Algoritma Tabu Search memiliki Lima langkah utama yang digunakan untuk menyelesaikan VRP, yaitu:

1. Representasi Solusi

Representasi solusi yang digunakan Algoritma Tabu Search untuk menyelesaian VRP adalah solusi feasible yang ditulis sebagai suatu urutan titik-titik (nodes), dimana tiap titik (node) hanya terlihat sekali dalam urutan. Titik (node) tersebut merepresentasikan depot dan konsumen.

2. Pembentukan Solusi Awal (Initial Solution)

Solusi Awal merupakan langkah pertama yang dilakukan dalam proses Algoritma Tabu Search. Solusi awal dapat dibentuk menggunakan metode random atau metode heuristik yang akan diperbaiki pada iterasi berikutnya. Langkah berikutnya mencari solusi Neighborhood. Solusi Neighborhood merupakan solusi alternatif yang diperoleh dengan melakukan perpindahan node (move). Setiap perpindahan node (move) akan menghasilkan satu solusi Neighborhood. Perpindahan 
node (move) dapat dilakukan menggunakan metode heuristik yaitu Exchange, 2-Opt, Cross Exchange dan Relocated.

3. Tabu List

Tabu list berisi atribut move yang telah ditemukan sebelumnya. Ukuran Tabu List akan bertambah seiring meningkatnya ukuran masalah agar dapat menghasilkan kualitas solusi yang baik. Ukuran Tabu List yang terlalu panjang tidak akan menghasilkan kualitas solusi yang baik karena dapat menyebabkan terlalu banyak perpindahan node (move) yang di larang [13].

4. Kriteria Aspirasi (Aspiration Criteria)

Kriteria aspirasi adalah suatu metode untuk membatalkan status tabu [13].

5. Kriteria Pemberhentian (Termination criteria)

Kriteria pemberhentian yang digunakan yaitu setelah semua iterasi yang telah ditentukan terpenuhi.

\section{Safety Stock}

Safety Stock adalah rata-rata produk yang dijadikan sebagai pengendalian dari risiko. Produk pengendalian ini juga dipengaruhi oleh service level yang mengikuti distribusi normal karena service level berkaitan erat dengan toleransi yang diberikan perusahaan atas tidak terpenuhinnya permintaan produk yang ada. Lead time adalah lamanya waktu antara mulai dilakukannya pemesanan bahan baku sampai dengan kedatangan bahan baku yang dipesan tersebut dan diterima di depot persediaan [16]. Rumusan dari total persediaan yang harus dipenuhi adalah Safety Stock, Perhitungan untuk mencari jumlah Safety Stock adalah sebagai berikut: [11].

$$
S S=Z \alpha \times S d l
$$

dan,

$$
\begin{gathered}
S d l=\sqrt{\left(d^{2} \times S l^{2}\right)+\left(l \times S d^{2}\right)} \\
S S=Z \alpha \times \sqrt{\left(d^{2} \times S l^{2}\right)+\left(l \times S d^{2}\right)}
\end{gathered}
$$

Selanjutnya untuk mencari nilai $S d$ dan $S l$ menggunakan persamaan berikut ini;

$$
S d=\sqrt{\frac{\sum_{i=1}^{n}\left(d_{i}-\bar{d}\right)^{2}}{r-1}}
$$

dan,

$$
S l=\sqrt{\frac{\sum_{i=1}^{n}\left(l_{i}-\bar{l}\right)^{2}}{r-1}}
$$

Keterangan:

$S S=$ Persediaan pengaman (Safety Stock)

$Z \alpha=$ Safety factor untuk resiko out stock

$S d=$ Standar deviasi permintaan perpriode

$S l=$ Standar deviasi lead Time

$d_{i}=$ Jumlah permintaan priode ke- $i$

$l_{i}=$ Jumlah lead time priode ke- $i$

$\bar{d} \quad=$ Rata-rata permintaan

$\bar{l} \quad=$ Rata-rata lead time

$r \quad=$ Ukuran sampel 


\section{Metode Penelitian}

Data yang digunakan dalam penelitian ini adalah data permintaan konsumen, jarak antar konsumen, jarak depot ke konsumen, kapasitas kendaraan PT IAP sebagai salah satu distributor air mineral untuk wilayah Daerah Istimewa Yogyakarta dan lama lead time. Diperoleh data dengan jumlah konsumen sebanyak 19, depot sebanyak satu, kapasitas maksimal kendaraan yaitu 60 karton, data lead time selama satu sampai tiga hari, serta jarak antar konsumen. Kemudian dapat dilakukan proses perhitungan dengan langkah-langkah sebagai berikut:

1. Pembentukan Solusi awal (initial solution)

Solusi awal pada pendistribusian produk air mineral ini dibentuk menggunakan metode heuristik Nearest Neighbor pada TSP.

2. Menentukan solusi Neighborhood dengan evaluasi move

Pada Algoritma Tabu Search, solusi Neighborhood merupakan solusi alternatif yang diperoleh dengan melakukan pertukaran node (move). Setiap perpindahan node (move) akan menghasilkan satu solusi Neighborhood. Perpindahan node (move) dilakukan menggunakan metode heuristik yaitu Exchange, Relocate, 2-Opt dan Cross Exchange.

3. Analisa solusi optimal VRP menggunakan Algoritma Tabu Search.

Solusi optimal diperoleh menggunakan Algoritma Tabu Search setelah semua iterasi dipenuhi.

\section{Hasil dan Pembahasan}

Penerapan Algoritma Tabu Search pada kasus pendistribusian produk air mineral menggunakan data permintan (Tabel 1) dan jarak (Tabel 2) sebagai berikut:

Tabel 1. Data permintaan konsumen produk air mineral.

\begin{tabular}{lll|lll}
\hline No. & Konsumen & Permintaan & No. & Konsumen & Permintaan \\
\hline 1 & A01 & - & 11 & A11 & 1 karton \\
2 & A02 & 25 karton & 12 & A12 & 2 karton \\
3 & A03 & 6 karton & 13 & A13 & 3 karton \\
4 & A04 & 2 karton & 14 & A14 & 2 karton \\
5 & A05 & 10 karton & 15 & A15 & 1 karton \\
6 & A06 & 11 karton & 16 & A16 & 2 karton \\
7 & A07 & 1 karton & 17 & A17 & 2 karton \\
8 & A08 & 1 karton & 18 & A18 & 2 karton \\
9 & A09 & 1 karton & 19 & A19 & 2 karton \\
10 & A10 & 1 karton & 20 & A20 & 2 karton \\
\hline
\end{tabular}

Tabel 2. Jarak depot ke konsumen dan antar konsumen dalam satuan kilometer.

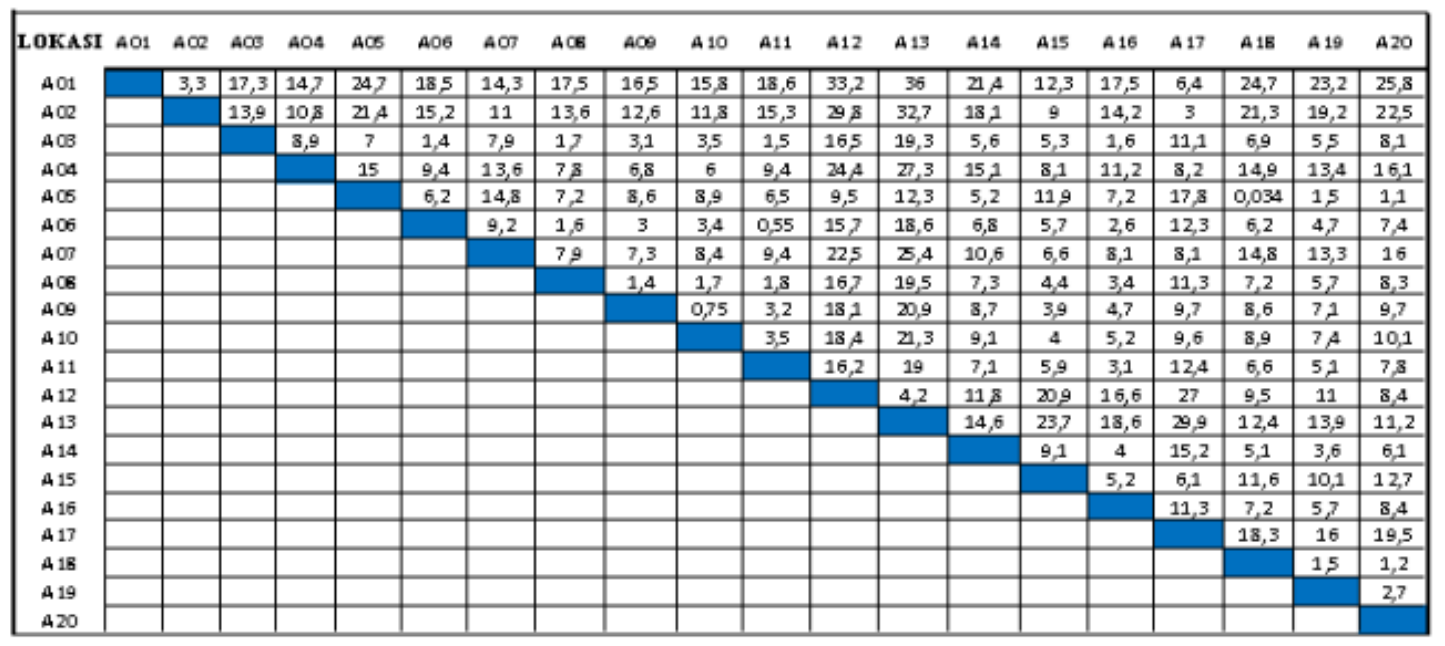


Kemudian proses perhitungan Algoritma Tabu Search secara manual dilakukan dengan langkahlangkah sebagai berikut:

1. Langkah pertama yang dilakukan adalah menentukan solusi awal sebagai solusi optimum pada iterasi ke-0 dengan metode Nearest Neighboor, diperoleh solusi TSP awal A01-A02-A17-A15-A09A10-A08-A06-A03-A11-A16-A14-A19-A05-A18-A20-A12-A13-A07-A04-A01. Solusi awal yang diperoleh kemudian dibatasi berdasarkan kapasitas kendaraan dan permintaan konsumen. Jika kapasitas kendaraan sudah tidak dapat memenuhi permintaan konsumen berikutnya maka kendaraan kembali lagi ke depot untuk mengisi muatan dan melanjutkan perjalanan dengan rute yang baru sampai semua node dikunjungi. Total permintaan tiap rute merupakan total permintaan tiap konsumen yang sudah dilewati oleh kendaraan pada tiap rute. Total jarak tiap rute merupakan jumlah jarak yang dilalui kendaraan saat mengantarkan pesanan kepada konsumen dalam tiap rute. Diperoleh rute VRP awal pada Tabel 3:

Tabel 3. Solusi awal VRP

\begin{tabular}{llcc}
\hline Rute & Solusi Awal VRP & Kapasitas & Jarak \\
\hline 1 & A01-A02-A17-A15-A09-A10-A08-A06-A03-A11-A16-A14-A19-A01 & & \\
& $0+25+2+1+1+1+1+11+6+1+2+2+2+0$ & 55 & 57,15 \\
\hline & $3,3+3+6,1+3,9+9,75+1,7+1,6+1,4+1,5+3,1+4+3,6+23,2$ & \\
\hline 2 & A01-A05-A18-A20-A12-A13-A07-A04-A01 & 22 & 92,234 \\
\hline & $0+10+2+2+2+3+1+2+0$ & & $\mathbf{1 4 9 , 3 8 4}$ \\
& $24,7+0,034+1,2+8,4+4,2+25,4+13,6+14,7$ & & \\
\hline
\end{tabular}

2. Langkah ke-2 yaitu menentukan iterasi selanjutnya dan mencari solusi Neighborhood TSP. Solusi Neighborhood TSP diperoleh dari node yang ditukar dan dihasilkan menggunakan empat metode Exchange, Relocate, 2-Opt atau Cross Exchange yang dipilih secara random sedemikian sehingga diperoleh solusi Neighborhood terbaik. Berikut merupakan salah satu solusi Neighborhood TSP yang diperoleh menggunakan metode Relocated pada solusi Neighborhood TSP ke sebelas.

Tabel 4. Salah satu solusi Neighborhood TSP menggunakan metode Relocated.

\begin{tabular}{|c|c|c|c|}
\hline No. & Metode & Solusi Neighborhood TSP & Jarak \\
\hline \multirow[t]{2}{*}{11} & Relocated & $\begin{array}{l}\text { A01-A02-A17-A15-A09-A10-A08-A11-A06-A03-A16-A14-A19-A05- } \\
\text { A18-A20-A12-A13-A07-A04-A01 }\end{array}$ & \\
\hline & A08 A11 & $\begin{array}{l}3,3+3+6,1+3,9+0,75+1,7+1,8+0,55+1,4+1,6+4+3,6+1,5+0,034+ \\
1,2+8,4+4,2+25,4+13,6+14,7\end{array}$ & 100,734 \\
\hline
\end{tabular}

3. Langkah selanjutnya yaitu memilih solusi terbaik diantara solusi Neighborhood yang telah diperoleh pada langkah sebelumnya. Solusi terbaik adalah solusi denga total jarak terpendek.

4. Setelah diperoleh solusi terbaik pada langkah sebelumnya maka node yang telah digunakann dimasukan kedalam tabu list sehingga tidak akan digunakan pada iterasi selanjutnya.

5. Proses Algoritma Tabu search diulang kembali mulai dari langkah 2 dan akan berhenti ketika kriteria pemberhentian terpenuhi. Diperoleh solusi optimal menggunakan Algoritma Tabu Search kemudian direpresentasikan pada peta Yogyakarta dan sekitarnya.

Tabel 5. Solusi Optimal VRP.

\begin{tabular}{llll}
\hline Rute & Solusi terbaik & Kapasitas & Jarak \\
\hline 1 & A01-A02-A04-A15-A06-A11-A08-A10-A09-A03-A16-A14-A19-A01 & 55 karton & $60,4 \mathrm{~km}$ \\
2 & A01-A05-A18-A20-A12-A13-A07-A17-A01 & $22 \mathrm{karton}$ & $78,834 \mathrm{~km}$ \\
\hline & Total & $\mathbf{7 7}$ karton & $\mathbf{1 3 8 , 8 3 4} \mathrm{km}$ \\
\hline
\end{tabular}


Rute terpendek yang diperoleh berdasarkan perhitungan manual yaitu sebesar 138,834 km.

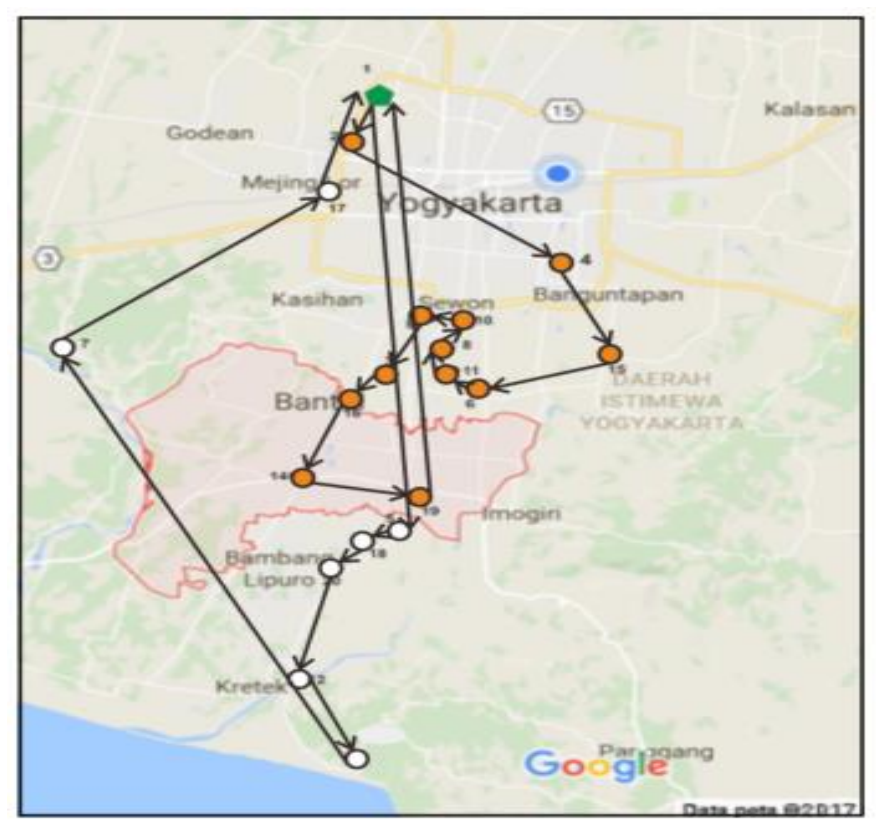

Gambar 1. Rute terpendek yang diperoleh.

Perhitungan sederhana Safety Stock dapat membantu menyelesaikan persediaan pengaman yang harus dipersiapkan oleh perusahaan dan mengurangi tingkat kerugian. Safety Stock dan CVRP merupakan dua permasalahan yang berbeda, tetapi saling terkait dalam proses pelayanan perusahaan terhadap konsumen.

Proses perhitungan sederhana persediaan pengaman (Safety Stock) untuk pendistribusian air mineral Daerah Istimewa Yogyakarta. Asumsi yang digunakan adalah sebagai berikut:

1). Menggunakan data laporan pemesanan konsumen sebelumnya.

2). Lead Time selama 1 sampai 3 hari.

3). Tingkat kepercayaan $(Z \alpha) 95 \%$

Tabel 6. Data laporan pemesanan.

\begin{tabular}{lllll}
\hline No & Tanggal & Total & Keterangan \\
\hline 1 & 07 Agustus 2017 & 71 karton & Senin pertama \\
2 & 14 Agustus 2017 & 55 karton & Senin kedua \\
3 & 21 Agustus 2017 & 95 karton & Senin ketiga \\
4 & 28 Agustus 2017 & 45 karton & Senin keempat \\
\hline
\end{tabular}

1. Akan dicari nilai Safety Stock dengan lead time 3 hari

$$
\begin{array}{ll}
l=3: 3: 3: 3 \text { hari } & \bar{d}=\frac{71+55+95+45}{4} \\
\bar{l}=\frac{3+3+3+3}{4} & \bar{d}=66,5 \\
\bar{l}=3 & d^{2}=4.422,25
\end{array}
$$


2. Akan ditentukan standar deviasi lead time $(S l)$

$$
\begin{aligned}
S l & =\sqrt{\frac{\sum_{i=1}^{4}\left(l_{i}-\bar{l}\right)^{2}}{r-1}} \\
& =\sqrt{\frac{(3-3)^{2}+(3-3)^{2}+(3-3)^{2}+(3-3)^{2}}{4-1}} \\
& =\sqrt{\frac{0}{3}} \\
& =0
\end{aligned}
$$

3. Akan ditentukan standar deviasi permintaan perpriode $(S d)$

$$
\begin{aligned}
S d & =\sqrt{\frac{\sum_{i=1}^{4}\left(d_{i}-\bar{d}\right)^{2}}{r-1}} \\
& =\sqrt{\frac{(71-66,5)^{2}+(55-66,5)^{2}+(95-66,5)^{2}+(45-66,5)^{2}}{4-1}} \\
& =21,809783737274
\end{aligned}
$$

4. Akan ditentukan standar deviasi permintaan dan lead time

$$
\begin{aligned}
S d l & =\sqrt{\left(d^{2} \times S l^{2}\right)+\left(l \times S d^{2}\right)} \\
& =\sqrt{(4.422,25 \times 0)+(3 \times 475,66666666667)} \\
& =\sqrt{478,66666666667} \\
& =21,878452108563 \\
S S & =Z \alpha \times S d l \\
& =Z \alpha \times \sqrt{\left(d^{2} \times S l^{2}\right)+\left(l \times S d^{2}\right)} \\
& =1,645 \times 21,8784521085 \\
& =35,990053718586
\end{aligned}
$$

Jadi, diperoleh nilai safety stock untuk lead time berbeda hari adalah 35,9900537185, sehingga dapat disimpulkan untuk total persediaan dengan lead time 3 harinya selama satu bulan \pm 35 karton. Berdasarkan data informasi yang diperoleh dari perusahaan dapat ditarik kesimpulan bahwa lead time 
cenderung konstan maka perhitungan sederhana Safety Stock akan menghasilkan nilai yang cenderung konstan juga. Berikut merupakan conter example untuk perhitungan Safety Stock.

1. Akan dicari nilai Safety Stock dengan lead time berbeda

$$
\begin{array}{ll}
l=1: 2: 3: 2 \text { hari } & \bar{d}=\frac{71+55+95+45}{4} \\
\bar{l}=\frac{1+2+3+2}{4} & \bar{d}=66,5 \\
\bar{l}=2 & d^{2}=4.422,25
\end{array}
$$

2. Akan ditentukan standar deviasi lead time $(S l)$

$$
\begin{aligned}
S l & =\sqrt{\frac{\sum_{i=1}^{4}\left(l_{i}-\bar{l}\right)^{2}}{r-1}} \\
& =\sqrt{\frac{(1-2)^{2}+(2-2)^{2}+(3-2)^{2}+(2-2)^{2}}{4-1}} \\
& =\sqrt{0,66666666667} \\
& =0,81649696580928
\end{aligned}
$$

3. Akan ditentukan standar deviasi permintaan perpriode $(S d)$

$$
\begin{aligned}
S d & =\sqrt{\frac{\sum_{i=1}^{4}\left(d_{i}-\bar{d}\right)^{2}}{r-1}} \\
& =\sqrt{\frac{(71-66,5)^{2}+(55-66,5)^{2}+(95-66,5)^{2}+(45-66,5)^{2}}{4-1}} \\
& =\sqrt{475,66666666667} \\
& =21,809783737274
\end{aligned}
$$

4. Akan ditentukan standar deviasi permintaan dan lead time

$$
\begin{aligned}
S d l & =\sqrt{\left(d^{2} \times S l^{2}\right)+\left(l \times S d^{2}\right)} \\
& =\sqrt{(4.422,25 \times 0,81649696580928)+(2 \times 475,66666666667)} \\
& =\sqrt{(3.610,75200500885)+(2 \times 475,66666666667)} \\
& =\sqrt{4.088,41867167552} \\
& =63,940743440122
\end{aligned}
$$




$$
\begin{aligned}
S S & =Z \alpha \times S d l \\
& =Z \alpha \times \sqrt{\left(d^{2} \times S l^{2}\right)+\left(l \times S d^{2}\right)} \\
& =1,645 \times 63,940743440122 \\
& =105,182522959001
\end{aligned}
$$

Jadi, diperoleh nilai safety stock untuk lead time berbeda hari adalah 105,182522959001, sehingga dapat disimpulkan untuk total persediaan dengan lead time yang harinya berbeda selama satu bulan 105 karton.

\section{Kesimpulan}

Berdasarkan hasil pembahasan tentang aplikasi Algoritma Tabu Search dan Safety Stock pada penentuan rute distribusi air mineral wilayah Daerah Istimewa Yogyakarta dapat ditarik kesimpulan sebagai berikut:

1. Proses perhitungan Algoritma Tabu Search terdiri dari Lima langkah. Langkah pertama yaitu menentukan solusi awal sebagai iterasi 0 dan menetapkan nilai solusi awal sebagai nilai solusi optimum sementara. Langkah kedua yaitu mencari solusi Neighborhood (solusi alternatif) yang tidak melanggar tabu atau memenuhi kriteria aspirasi. Langkah ketiga yaitu memilih solusi terbaik diantara solusi Neighborhood pada tiap iterasi yang akan disimpan sebagai solusi optimum. Langkah keempat yaitu memperbarui Tabu List dengan memasukkan node yang telah digunakan pada pertukaran node di langkah ketiga. Langkah terakhir yaitu apabila kriteria pemberhentian dipenuhi maka proses perhitungan Algoritma Tabu Search berhenti dan diperoleh solusi terbaik (optimum), jika tidak dipenuhi maka proses kembali berulang dimulai pada langkah kedua.

2. Pada kasus perusahaan air mineral diperoleh solusi terbaik (optimum) dengan menggunakan Algoritma Tabu Search. Jarak terpendek yang diperoleh menggunakan perhitungan manual adalah $138,834 \mathrm{~km}$. Berdasarkan hasil perhitungan dihasilkan solusi rute:

Tabel 6. Solusi rute terbaik (optimum).

\begin{tabular}{llll}
\hline Rute & Solusi terbaik & Kapasitas & Jarak \\
\hline 1 & A01-A02-A04-A15-A06-A11-A08-A10-A09-A03-A16-A14-A19-A01 & 55 karton & $60,4 \mathrm{~km}$ \\
2 & A01-A05-A18-A20-A12-A13-A07-A17-A01 & 22 karton & $\mathbf{7 8 , 8 3 4 ~ k m ~}$ \\
\hline & Total & $\mathbf{7 7}$ karton & $\mathbf{1 3 8 , 8 3 4} \mathbf{k m}$ \\
\hline
\end{tabular}

3. Nilai Safety Stock yang diperoleh dengan kasus perusahaan air mineral yang mengalami lead time satu sampai tiga hari adalah penambahan \pm 35 karton di gudang sebagai Safety Stock selama satu bulan.

\section{Referensi}

[1] Alkallak, Isra Natheer, \& Shaban, Ruqaya Z. 2008. Tabu Search Method For Solving The Traveling Salesman Problem. Raf. J. of Comp. \& Maths. 5:141-153

[2] Al-Mahally, Imam Jalaluddin \& Imam Jalaluddin As-suyutti. 1990. Tafsir Jalalain Berikut Asbab Annujulnya, Jilid I. Bandung: Penerbit Sinar Baru.

[3] Ballou, Ronald H. 2006. Bussiness Logistic Management. United State: Prenticehall.

[4] Christopher, Martin. 2011. Logistics \& Supply Chain Management Fourt Edition. United Stated of America: Prentice Hall, Inc.

[5] Cordeau, J.F., Laporte, G., Savelsbergh, M.W., et al. 2002. Vehicle Routing. Handbook on OR \& MS.

[6] Gendreau, M. Hertz, A. G. Laporte. 1994. A Tabu Search Heuristic for the Vehicle Routing Problem. Management Science.

[7] Glover, F \& Kochenberger, G.A. (Eds). 2003. Handbook of Metaheuristics. Dordrecht: Kluwer Academic Publisher.

[8] Glover, F \& Laguna, M. 1997. Tabu Search. Massachusetts: Kluwer Academic Publisher.

[9] Glover, F \& Marti, R. 2006. Metaheuristic Produres for Training Neural Networks. Alba and Marti (Eds.).Springer. 
[10] Gooddairrie, Edgar G. \& Parmenter, Michael M. 2002. Discrete Mathematics with Graph Theory Second Edition. United States of America: Prentice-Hall, Inc.

[11] Heyzer, Jay \& Barry, Render. 2005. Operation management, 7 Th edition. Jakarta: Penerbit salemba empat.

[12] Kallehauge, B., J. Larsen, dan O.B.G. Marsen. 2001. Lagrangean duality applied on vehicle routing problem with time windows. Technical Report. IMM. Technical University of Denmark.

[13] Kismono, Gugup. 2001. Pengantar bisnis, Edisi pertama. Yogyakarta: BPFE. Indonesia.

[14] Kusumadewi, S., \& Purnomo, H. 2005. Penyelesaian Masalah Optimasi dengan Teknik-Teknik Heuristik. Yogyakarta: Graha Ilmu. Indonesia.

[15] Manongga, Danny dan Nataliani, Yessica. 2013. Matematika Diskrit. Jakarta: Prenadamedia Group. Indonesia.

[16] Nasution, Arman \& Prasetyawan, Yudha. 2008. Perencanaan Dan Pengendalian Produksi. Yogyakarta: Graha IImu Indonesia.

[17] Nurmatias. 2010. Penentuan Stock Material Chemical dengan Simulasi Monte Carlo. Jurnal Universitas Islam Indonesia. Yogyakarta.

[18] Pakpahan, Efendi. 2009. Manajemen Pemasaran. Yogyakarta: BPFE. Indonesia.

[19] Parwadi, Moengin. 2011. Metode Optimasi. Bandung: Muara Indah. Indonesia.

[20] Raditya, Aji. 2009. Penggunaan Metode Heuristik dalam Permasalahan Vehicle Routing Problem dan Implementasinya di PT Nippon Indosari Corpindo.Skripsi, tidak diterbitkan, Institut Pertanian Bogor.

[21] Rahmat, Basuki. 2011. Perbandingan Genetic Algorithm, Multiple Ant Colony System, dan Tabu Search untuk Penyelesaian Vehicle Routing Problem With Time Windows (VRPTW).Jawa Timur.

[22] Rosen, Kenneth H. 2012. Discrete Mathematics and Its Application Seventh Edition. NewYork: Mc-Graw-Hill.

[23] Salaki, D.T. 2009. Penyelesaian vehicle routing problem menggunakan beberapa metode heuristic konstruktif. Tesis. Bogor. Sekolah pasca sarjana institute pertanian.

[24] Siregar, W.D. 2012. Analisis kualitas Fisik, Biologi, dan Kimia pada Air Minum dalam Kemasan barbagai merk yang dijual di Kota Medan. Fakultas kesehatan masyarakat. Universitas Sumatera utara. Medan.

[25] Solomon, M \& Desrosiers, J. 1988. Time window constrained routing and scheduling Problems.Transportation science.

[26] Sulistiono. 2015. Rancang Bangun Vehicle Routing Problem Menggunakan Algoritma Tabu Search. Skripsi, tidak diterbitkan. UIN Sunan Kalijaga: Yogyakarta.

[27] Suyanto. 2010. Algoritma Optimasi Deterministik atau Probabilitik. Yogyakarta: Graha Ilmu.

[28] Taha, H. A. 2003. Operations Research: An Introduction seventh Edition. Prentice Hall, Inc.

[29] Tarantilis, C. D., loannou, G., Kiranoudis, C. T., dan Prasdacos, G. P. 2005.Solving the open vehicle routing problem via sing/e parameter meta-heuristic algorithm. Journal of the Operational research Society.

[30] Tjiptono, Fandy. 2008. Strategi Pemasaran. Yogyakarta: Penerbit Andi. Indonesia.

[31] Tonci Caric, Hrvoje Gold. 2008. Vehicle Routing Problem. University of Zagreb: In-teh Croatia.

[32] Toth, P., \& Vigo. D. 2002. Vehicle Routing Problem, Methods, and Applications Second Edition. Philadelphia: Society for Industrial and Applied Mathematics. 